\title{
Me am Petri
}

Information overload.

\section{Martin Hayes}

Dr Richard Finch left the lab on the Friday afternoon of the long weekend. He was looking forward to a few days R\&R. Stress wasn't even the word for it. It was only two days since an asteroid the size of a microwave oven had smashed into the park just across the road. Things were still pretty crazy. It had taken three hours just for the clouds of dust to abate. The Fire Chief had been on the national news explaining how it was a miracle that no one had been killed.

The lab was a write-off. The impact had emptied shelves and uprooted benches, but it could have been worse. They had been winding this facility down even before the asteroid hit, which meant that the viable embryos had already been moved to the new building across town.

Finch was the only person working in the lab that week, tidying things away while his colleagues got the new facility up and running. All that the lab contained now was a selection of old and obsolete equipment and a freezer full of unviable embryos awaiting destruction. And that was just as well - because the impact had upturned the cryo-freezer and spilled its contents all over the floor. Finch had swept up and safely disposed of the vast majority of the detritus, but as he left the lab with a spring in his step he did not notice the dustpan full of broken test tubes and Petri dishes that he had left on the bench. Nor did he notice that the blast had cracked one of the lab's large windows, and that a light breeze was wafting in as he pulled the door shut.

Me...

Me ... light...

Me sense light...

Me sense light on photosensitive cells amassing on back of mass that is me.

Me grow pit in back. Me feel cells drift into pit in back. Me feel opening of pit get smaller. Me focus light now. Me see shapes.

Me think about shapes me sees.

Me begin to think more and more.

Me am Petri.

Me spread tendrils over lip of glass shell that houses Petri.

Me outgrow shell. Me spread across flat plane that supports shell.

Me sense heat from distant star. Me try to remember stars from long time gone. Me was part of something bigger. Something much bigger than what Me am now.

Me's tendrils sense tickly air near faint source of heat on plane that supports shell.

Me grows tendrils towards tickles. Me feels heat and new wind. Me's tendrils stroke shape that Me sees inside Me's mass.

Me slips tendrils deeper in. Me touches something strange. Me frightened. Me get too much information. Me stung by surge of information. Me pull tendrils away. But Me like tickles. Me put tendrils back in deep.

Me learn about history of plane on which plane that supports shell stands. Me unhappy. Me scared. Me know that locals will not like Me. Me flickers tendrils. Me accesses new information. Me learn local name of source of heat in sky. Me 'reads'. Me know that locals call it 'reads'. Me reads information to do with probable imminent demise of locals. Me reads locals know it and do not care. But for some. Who do care. Who are called liars. Me feel sad. Me feel sad for silly locals.

Me flicker tendrils again.

Me cannot stop surge of information.

Me learn how to cook perfect duck confit.

Me learn name of big star footballer's lover... "She didn't mean to be a homewrecker."

Me see man sit on glass jar and glass jar breaks. Man sad. Me sad.

Me see woman crash car. Me now know "Stupid Blondes Can’t Drive!"

Me see many strange protrusions being slipped in and out of many openings.

Me see incredible, jaw-dropping feats of local's ingenuity and imagination. Me see these feats are "FAKE!!!"

Me see locals complain that local in charge wants them to be healthy. Locals hate local chief for it. Locals must want to be sick. Locals are stupid.

Me learn "FAIL" and "EPIC" and "EPIC WIN!"

Me wants cheezburger.

Me sees cat do funny thing. Me ROFL.

Me now think that every local should have his say. No matter how ill-informed or obviously stupid local is. Me can't help but absorb stupid local's unsustainable reactionary opinions.

Me think all paediatricians should be killed.

Me on social networking site trying to form angry mob to kill all paediatricians.

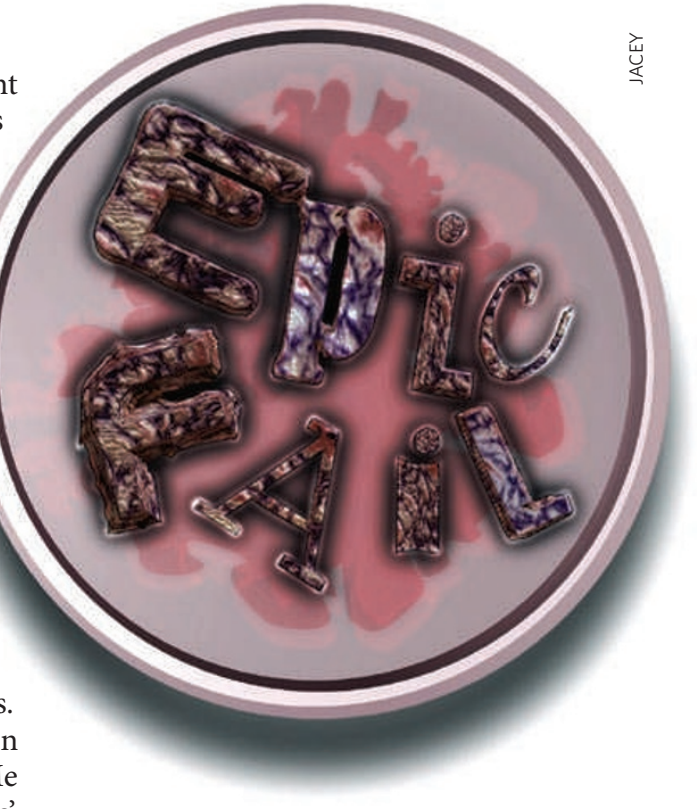

Me overwhelmed with anger and stupidity.

Me PWNED by Sword of Gondor in debate over local gun law.

Me want gun now.

Me wish me never came here to this plane. Me want to leave here. Me miss quiet.

Me bored of LATINACHICKBOYS.

Me have rudimentary arm now. Me can feel me's form and shape. Me does not like what me feels. Too thick. Me want to be slim.

Me hate Me now.

Me hate everything now.

Everything stupid. Everything EPIC FAIL!!!

Dr Finch returned to the lab on the wet Tuesday morning following the long weekend. He dropped his morning coffee as he stared in horror at the primitive, misshapen and strangely humanoid life form that lay dead across his desk. It had one stumpy arm and a large rudimentary eye in the centre of its semi-transparent back. Long, moss-like tendrils had spread from the edges of the creature's mass and inched their way into his computer.

He took a step closer, his mouth hanging open, and nudged the mass of tissue with the point of his umbrella.

It did not move. It had slit its own throat with his letter opener.

Martin Hayes is an Irishman abroad in his own country. He potters about and tends to drink a lot of Guinness in the afternoon. You can visit him at www.paroneiria.com. 